\title{
Creating and Implementing Communicative Tasks According to VanPatten's Principles
}

\section{Stephen Clarke \\ Nagoya College \\ Chris Hastings \\ Aichi Prefectural University}

\section{Reference Data:}

Clarke, S. J., \& Hastings, C. R. (2020). Creating and implementing communicative Tasks according to VanPatten's principles. In P. Clements, A. Krause, \& R. Gentry (Eds.), Teacher efficacy, learner agency. Tokyo: JALT. https://doi.org/10.37546/JALTPCP2019-46

In this paper aimed at practitioners, the authors introduce their interpretation of an approach to communicative language teaching proposed by the SLA scholar Bill VanPatten that involves the use of Tasks as key elements in the curriculum. While the notion of task-based learning is not new, VanPatten's approach differs fundamentally from other conceptions, especially in the way it focuses on a definition of communication and in its rejection of the explicit teaching of grammar. VanPatten (2017) introduces six principles of communicative language teaching which can be used as a framework for designing and implementing Tasks. In the following order, this paper outlines the principles as they relate to Task design, gives an example of a communicative Task created by the authors which reflects VanPatten's principles, and finally offers considerations for classroom implementation.

実践者を対象とした本論文では、SLAの学者であるBill VanPattenによって提案された、カリキュラムの主な要素としてタス クを使用することを含む、コミュニカティブ・ランゲージ・ティーチングへのアプローチの解釈を紹介する。タスクに基づく言 語指導法の概念は新しいものではないが、VanPattenのアプローチは他の概念とは根本的に異なり、特にコミユニケーション 定義に焦点を当てている点と、文法の明白な指導を否定している点が異なっている。VanPatten (2017) は、タスク設計および

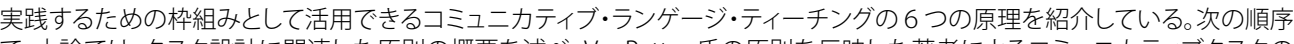
で、本論では、タスク設計に関連した原則の概要を述べ、VanPatten氏の原則を反映した著者によるコミユニカテイブタスクの 例を示し、最後に授業での実践に関する考慮事項を提案する。 nterest in communicative approaches and task-based language learning and teaching (TBLT) has been growing in Japan since the Ministry of Education (MEXT) implemented a new plan for English education in 2003 (MEXT, 2002). Additionally, MEXT's (2009) New Course of Study guidelines, announced in 2009, reemphasised the need for teachers to move from grammar translation-based to more communicative approaches. However, critics such as Tahira (2012) argue that communicative approaches are poorly understood by teachers in Japan and MEXT's lack of commitment and support is a contributing factor. Furthermore, most TBLT occurring in Japan is a weak form of frameworks promoted by scholars such as Jane Willis (1996) and Mike Long (2014) and can be categorised as task-supported rather than task-based; explicit teaching of grammar remains the main unit of the curriculum (Kotaka, 2013). In this paper, we argue that VanPatten's (2017) radically different approach to the concept of communicative Tasks ("Task" with a capital "T" is used throughout this paper to refer to those that are genuinely communicative) exposes fundamental problems with these TBLT frameworks. It enables teachers to easily conceptualise "communicativeness" and provides a practical approach to creating and using Tasks.

VanPatten presents a radical critique of mainstream language teaching, arguing that SLA research findings have been poorly communicated or ignored. Since most classroom instructors in Japan are unfamiliar with his work, we provide a brief outline of his main arguments and invite readers who wish to understand more deeply to refer to his published works (e.g., Lee \& VanPatten 2003; VanPatten, 2003, 2017) and his podcast TalkinL2withBVP (e.g., VanPatten, 2019, 2019c). As an introduction, it is useful to consider his six principles of communicative language teaching (VanPatten, 2017).

1. Teaching communicatively implies a definition of communication.

2. Language is too abstract and complex to teach and learn explicitly.

3. Language acquisition is constrained by internal and external factors.

4. Instructors and materials should provide appropriate level input (and interaction). 
5. Tasks should form the backbone of the communicative curriculum.

6. Any focus on form should be input-oriented and meaning-based.

In the next section, we will discuss practical implications of VanPatten's principles.

Principles and Their Implications for Task Design

\section{Definition of Communication}

VanPatten (2017) contends that language classroom practice should be informed by facts from SLA research and that instructors who wish to teach communicatively and towards proficiency should have clear definitions of communication and language. Without a clear definition of communication, instructors cannot know whether they are creating communicative events in their classroom or not and if one accepts the premise that learners learn how to communicate by communicating, then it becomes essential to define the term. To our knowledge, VanPatten is the only scholar who attaches such importance to the definition of one of the most basic terms in our field, which is surprising and highlights a flaw in the progress of the field. The concept of communication has appeared so evident to most teachers and theorists that they have failed to consider some of its essential characteristics. Building on the description of communication by Savignon (1997, p. 14) as "a continuous process of expression, interpretation, and negotiation of meaning", VanPatten (2019b) proposes the following definition: "Communication involves the expression, interpretation and sometimes negotiation of meaning in a given context for a given non-linguistic purpose". Thus, Tasks should include three major features.

Firstly, they should allow learners to express, interpret, and negotiate meaning. This point is uncontroversial, and most teachers interpret communicative language teaching in such a way.

Secondly, Tasks should have a clear, overall communicative goal. Giving tasks clearly-defined communicative goals is also adopted by other proponents of task-based learning (see Long, 2014; Willis, 1996), although they do not refer to a definition of communication. It is self-evident that any Task should have a language-learning goal, otherwise it would not be appropriate for a language classroom. However, this does not imply that a Task also possesses a specific language goal, for example to practice the past tense. Language practice does not feature in the proposed definition of communication, which "informs what it means for a classroom to be communicative" (Van Patten, 2017, p. 45) and so it should not feature in communicative Tasks. Since the 1970s it has been a widely held, if often ignored or downplayed assumption, that learners acquire language and develop skills through the act of communicating. VanPatten (2017) argues forcefully that classroom Tasks should involve learners engaging in communicative events. Therefore, Task goals should feature goals that are typical of genuine communication.

What we have described as communicative goals are in fact, nonlinguistic. VanPatten (2017) points out that communication has three purposes: cognitive-informational, psycho-social, and to a lesser extent, entertainment. Respectively, these mean to obtain information, to develop and maintain relationships, and for recreation. Only the first type is suitable for communicative Tasks. Although instructors generally want their lessons to be interesting, a teacher's primary role is not to entertain. Since the kind of relationships that learners and teachers can develop is dictated by both the classroom environment and social factors, learners are best left to pursue their own psycho-social goals outside class. By completing a Task, learners should learn something interesting about themselves or the world around them, which, of course, includes their classmates (VanPatten, 2017). It follows then, that Tasks should have a clear cognitive-informational goal. The information presented in a Task has to be real since fake or made-up information does not lead to genuine learning about the world. Many published teaching materials contain activities with fabricated information and which lead to the practice of predetermined language items. Therefore the goal is linguistic - to practice languageand this is not a feature of communication as VanPatten defines it. We can only conclude that much of contemporary language teaching is not communicative.

Thirdly, teachers who wish to create Tasks should be mindful of the constraints that the classroom context brings. VanPatten (2017) argues, "in classrooms, context exerts a major and hidden constraint on communication. This is because the context never changes" (p. 26). If genuine communication is to take place in the classroom, learners' goals have to fit in with the reality of who and where they are. Role-play activities have been long been adopted in so-called "communicative" classrooms, but VanPatten argues that they attempt to change the setting and the participants of the interaction, and because the context is fixed, this is impossible. Also, we cannot evade the social dynamics of the classroom, in which learners know that their instructor has more power than them and that they are likely to be graded on their performance. Any attempt at recreating "the real world" inside the classroom is doomed to failure. As a result, we can only conclude that role-plays are not genuinely communicative events and therefore cannot be regarded as communicative Tasks.

\section{The Nature of Language and Language Acquisition}

VanPatten is a distinguished SLA scholar and we offer the four points below as a brief summary of his position. 
1. It is impossible for explicit knowledge to become part of a learner's acquired system.

2. Textbook grammar bears no relation to the grammatical systems that language acquirers construct in their heads.

3. Learners only acquire language through exposure to input in communicative contexts.

4. Teachers cannot control the underlying processes of language acquisition.

Readers who are interested in VanPatten's interpretation of SLA research data should consult his published works (e.g., VanPatten, 2016; Van Patten \& Rothman, 2014) or podcasts (e.g., VanPatten, 2019, 2019c). Some, or all, of the points above may be controversial to some but we find VanPatten's arguments compelling and encourage readers to study them for themselves.

Moving our discussion forward, we will comment on the implications of VanPatten's position on SLA for Task design and implementation. Firstly, instructors should not concern themselves with covering certain language forms or organising classes around grammar. This stands in contrast to the approach to TBLT associated with Jane Willis, who has argued that a task-based approach can be made to fit in with traditional textbooks and a grammatical syllabus (Willis, 1996). Instead of teaching grammar, instructors should focus on providing lots of rich and interesting communicatively embedded input in their Tasks. Moreover, since exposure to communicatively embedded input is the only way in which learners acquire a language, Van Patten (2017) argues that focus on form (FonF) is optional, and it should be based on understanding meaning rather than through explanation and practice. This stands in direct opposition to Long (2014) and Willis (1996), who see FonF as an essential part of task-based learning. It may be daunting for many teachers to consider dropping many of their conventional techniques, but we would encourage teachers to consider how they can justify traditional grammar-based teaching according to what is now known about the nature of language and of second language acquisition.

\section{Input and Interaction}

The fourth principle states that "instructors and materials should provide appropriate level input (and interaction)" (VanPatten, 2017). In other words, the instructor's main responsibility is to have learners respond to input (language that students see or hear) that they can understand and find engaging and that is designed to help them interact with their classmates and teacher. We have tried to apply this principle to our example Task by choosing a content area and goal that is interesting to our learners, by incorporating repeated exposure to useful language forms, and by integrating opportunities for information and opinion exchange. During the latter, learners may need to negotiate meaning due to gaps in knowledge and understanding. If students are negotiating meaning, then they are necessarily interacting with their teacher or their classmates. Interaction is much more than this, however. Broadly speaking, interaction involves learners demonstrating that they have understood a message (VanPatten, 2019a). In order to provide level-appropriate input, instructors need to know how much their learners can comprehend, so interaction is an essential part of classroom practice.

Tasks as the Basis of the Curriculum

The fifth principle states that "Tasks should form the backbone of the communicative curriculum", meaning that they can be used to organise a course of study and as a means of assessment (VanPatten, 2017). Tasks are designed to align themselves with the proposed definition of communication and are therefore fully communicative events. However, not everything instructors do in the classroom needs to be a Task (VanPatten, 2017). Indeed, it would be difficult to do so in practice, because the learners in a given classroom may need to be exposed to certain language items before they can complete a given task successfully. Activities that are only partially communicative (for example, those that include the expression and interpretation of meaning but lack a cognitiveinformational purpose), may have a role to play in task-based teaching, as long as they serve to enable learners to complete a certain Task.

\section{Communicative Tasks in Practice}

Technology Task

Since this paper is practice-oriented, we will demonstrate how we have applied VanPatten's (2017) principles to create an example Task and encourage readers to do the same. The overall goal is for learners to gain information about their technology and smartphone use and decide whether they should change their habits. This goal is clearly nonlinguistic and is explicitly stated at the beginning of instruction. Learners must exchange information about technology use in order to complete all the various steps of the Task. The sequence could be described as a series of miniTasks with a final capping Task that requires learners to summarise and synthesise their information. 
Step One. Introduction: What Technology Habits Are Normal or Excessive?

Learners read a list of technology habits (Appendix A), check whether they think they are normal or excessive, compare their responses with a partner, and, if possible, give reasons for their choices. It is important to note that output here is encouraged but not forced.

This first step is mostly input based and introduces the learners to the theme of the Task as well as giving them vocabulary and phrases that they can use in later stages. In contrast, many textbooks begin a unit or chapter with a list of discussion questions that require the learners to perform forced output for unclear reasons and then do nothing with the information produced. The pretask stage of TBLT frameworks sometimes include this kind of activity, the rationale being that it activates schema, but if the goal is to leverage learners' prior knowledge, schema building can be achieved by having learners interact with input.

\section{Step Two. Pair work: Electronic Device Survey}

Learners answer a survey on general technology use (Appendix B), then interview a partner and input their partner's answers into Google Forms, which calculates a class average. Then the learner writes a short paragraph comparing his or her results with the rest of the class. Thus, this stage starts off again with interaction with relevant and comprehensible input. The model paragraph uses text enhancement to draw learners' attention to vocabulary and language forms that may be useful in completing their own paragraph. However, learners are not required to use any specific vocabulary or language forms. Depending on the expressive ability of the group, the Task could be adapted to require them to create the survey questions themselves.

Step Three. Group work: Smartphone Use Survey (Length of Time, Frequency)

Learners answer a survey on general smartphone use, interview a partner, and again input the answers into Google Forms. After looking at the results and class averages, the learner exchanges opinions about them with a partner, then writes a short paragraph comparing his or her results with the rest of the class. This stage is similar to the previous stage except there is an opinion-gap miniTask in which learners compare their opinions about the survey results. The purpose of this is to provide learners with further interesting information that can be used in the final written wrap-up.
Step Four. Learn About the Wider World: The Benefits and Dangers of Smartphone Use

Learners read one of three infographics (Appendix C) to learn about the benefits and dangers of smartphones. Then they exchange information and opinions with two other classmates who read different texts. This step is recognisable to readers as an information-gap activity. Learners are asked to choose the two most interesting or surprising facts from their infographic and share this information with a partner. The information they receive from their partner is necessary to enable them to learn about the world and judge their own smartphone habits, thereby completing the final stage of the Task. Therefore, learner interaction has a genuine communicative purpose. Compared to previous stages, step four provides more linguistically complex input with fewer examples of specific forms for learners to use in output. This escalation of demands on the learner is deliberate so as to produce increased opportunities for purposeful output, lengthier interactions, and negotiation of meaning. This should be achievable due to familiarity with the topic and related language in previous stages.

Step Five. Reflection and Conclusions: What I Learned From This Task Finally, learners write a short essay about what they learned about their technology habits and whether they think it is necessary to change them. This output could be adapted into an oral presentation or recording depending on the time available and what skills the teachers wishes to focus on. It could even be adapted into something project based such as producing a YouTube video, a podcast, or a Wikipedia webpage.

This final step acts a capping task, a way to reflect on the information gained from the previous miniTasks. It also provides learners with a sense of completion. Any final writing Task should have a clear communicative purpose and should not merely summarise the previous steps of a Task; learners should analyse and evaluate information from previous steps and then create an original conclusion. In our example, learners need to analyse the results from the technology surveys, evaluate the benefits and risks of smartphones, and then create recommendations for general smartphone use. Recently, digital health has become an important issue, so by completing this Task learners will gain useful information to improve the quality of their health. The writing process should not be too painstaking, and the task progression should have provided learners with a lot of linguistic support.

Tasks need not be as elaborate with as many stages as the one we present; some may be completed in one lesson, for example. It depends on the topic and the learners' and 
teacher's aims. Readers may find similarities between our example Task and activities from content-based learning and project-based learning approaches. However, contentand project-based learning may have an explicit language teaching component and, because they are not informed by a definition of communication, they may not involve genuinely communicative interaction at their core.

\section{Building Tasks}

Topic Choice and Working Backwards

When creating communicative Tasks, the first thing to consider is the overarching Task goal and whether the learners will find the topic meaningful and engaging. As it can be challenging to reconcile learners' proficiency and their interests, careful consideration of goals and topics may be required. Below are several examples of topics and goals that the authors have successfully used to create Tasks for their classes of first- and second-year English language major college students. Teachers interested in using these Tasks are welcome to contact the authors.

- Travel: Learn which of your classmates is a compatible travel partner and then create an itinerary for a short trip with them.

- Education: Learn about the American school system, compare it to the Japanese system, and then create a "perfect" school using parts from each system.

- Personality: Learn about personality traits and compare your personality to a classmate's.

- Health: Ask classmates about habits related to food, sleep, and physical activity to learn how healthy the class is.

Following goal selection, the next step is to work backwards to break the Task into steps and activities to ensure learners have the linguistic resources to complete the task (VanPatten, 2017). Teachers should consider the expressive ability of their learners to decide whether to make the Task input- or output-based.

\section{Task Components}

Our example Task required learners to obtain, analyse, synthesise, and evaluate information from classmates, demonstrating how surveys, interviews, short summarising paragraphs, and a final written wrap-up can be used. Other components and resources that may be useful are rankings, discourse scrambles, infographics, census or government data, and jigsaw activities.

\section{Considerations for the Classroom}

Optimal implementation of communicative Tasks requires consideration of the following topics: the learners and learning context, the teacher's role, creating a course of study, and assessment.

The Learners and Learning Context

Both the authors implemented a communicative Task-based curriculum with firstyear and second-year English language majors in Japanese tertiary education. We were free to create and deliver curriculums without prescribed components or institutional constraints. Learners generally had a positive attitude towards the courses, which was evident from their engagement, use of $\mathrm{L} 2$, and completion of the Tasks. However, teachers wishing to implement communicative Tasks in their classes successfully should be aware of several points of concern. For instance, Gorsuch (2000) observed that Japanese learners have reservations about task-based approaches in contexts where there is high-stakes testing (for example, the Center Exam for university entrance), and when they have not experienced such an approach before. Therefore, it may be necessary for teachers to explain to learners, who have typically spent their secondary school English classes explicitly studying grammatical knowledge for test preparation, that implicit knowledge acquired through communicative interaction also has a role to play in improving their test performance. Additionally, a transitional period and a clear explanation of the rationale for this approach provided in the L1 may be needed.

\section{The Teacher's Role}

In contrast to much traditional pedagogy, including the widely used PPP (present, practice, produce) approach, teachers do not take a central role in the classroom as a knowledge transmitter. Instead, they act as facilitators. Typical duties fulfilled by the teacher during classes include the following:

- explaining the overall Task goal and any mini-task goals;

- monitoring for understanding and progress;

- providing L1 support as necessary;

- ensuring learners progress through all the stages;

- encouraging learners to use their dictionaries or ask questions when they do not understand something; and 
- providing additional examples of language items that may be used to complete output sections of the Task.

\section{Creating a Course of Study}

The authors' courses at the tertiary level were based on 15-week semesters. It is usually an institutional requirement to create a syllabus in advance of actually teaching a course. However, in reality, the syllabus can be negotiated with learners in the first class. For example, teachers can explain what communicative Tasks are, why they promote language acquisition, and the learners' and teacher's role in the class. Subsequently, instructors can provide learners with a list of Tasks and explain that each takes a few classes to complete (in our case, usually two to three). Then the whole class can be involved in choosing topics or Task types that appeal to them. Tasks can be added or removed during the semester according to the pace of progress. Two advantages arise from this approach: learners are more invested in the course by being given choice and without a traditional textbook there is no pressure to arbitrarily finish a certain number of units.

\section{Assessment}

College instructors are usually required to formally assess learners at the end of each semester. A simple way to achieve this is to follow VanPatten's (2017) recommendation to use Tasks themselves as a means of assessment. For example, learners can record themselves completing part of a task and the instructor can refer to can-do statements to assign a grade. A list of can-do statements relating to the final step of our Technology Task could be as follows:

\section{The learner}

1. can categorise two kinds of technology habits as normal or excessive and provide reasons.

2. can compare three technology and smartphone habits to the class average and comment on the differences.

3. can explain two benefits and two dangers of smartphones and provide reasons.

4. can give two pieces of advice based on these benefits and dangers.

5. can explain why or why not he or she will change his or her technology habits and provide reasons.
To create a numerical grade, instructors can assign two points if a learner can successfully complete the can-do statement, one point if he or she can nearly do it, and zero points if he or she cannot do it.

\section{Conclusion}

VanPatten's (2017) six principles provide a framework for communicative language teaching that is informed by SLA research findings as well as a clear and comprehensive definition of communication. They offer a clear-sighted and theoretically convincing approach to the creation and use of communicative Tasks in the classroom and point out flaws in other proposed versions of task-based learning. They also require teachers to reevaluate traditional practice. Some teachers may be concerned by the apparent constraints they impose and the traditional activities that they dismiss. If the field is to move forward, however, it is essential to base our practice on what has been learned from 50 years of SLA research, as well as on clear definitions of our terms. Adopting VanPatten's approach enables teachers to embrace the view, first proposed in the 1970 s, that the way learners learn to communicate is through communicating. Hopefully this paper has provided inspiration to teachers as well examples of how to implement truly communicative Tasks.

\section{Bio Data}

Stephen Clarke is an assistant professor at Nagoya College. His research interests are communicative tasks, story listening and pronunciation instruction. <sjclarke@ nagoyacollege.ac.jp>

Chris Hastings is a lecturer at Aichi Prefectural University. His research interests are communicative tasks, game-based learning, and virtual reality as a pedagogic medium. $<$ hastings@for.aichi-pu.ac.jp>

\section{References}

Gorsuch, G. (2000). EFL educational policies and educational cultures: influences on teachers' approval of communicative activities. TESOL Quarterly, 34(4), 675-710. https://doi. org/10.2307/3587781

Kotaka, M. (2013). Task-based language teaching (TBLT) and the Japanese English classroom. 者 留文科大学大学院紀要 [The Tsuru University Graduate School Review], 17, 47-70. Retrieved from http://trail.tsuru.ac.jp/dspace/handle/trair/629 
Lee, J., \& VanPatten, B. (2003). Making communicative language teaching happen (2nd ed.). New York, NY: McGraw-Hill.

Long, M. (2014). Second language acquisition and task-based language teaching. n.p.: John Wiley \& Sons.

MEXT. (2002). Developing a strategic plan to cultivate "Japanese with English abilities." Retrieved from https://www.mext.go.jp/b_menu/hakusho/html/hpac200201/hpac200201_2_015.html

MEXT. (2009). Improvement of academic abilities (courses of study). Retrieved from https://www. mext.go.jp/en/policy/education/elsec/title02/detail02/1373859.htm

Sato, R. (2010). Reconsidering the effectiveness and suitability of PPP and TBLT in the Japanese EFL classroom. JALT Journal, 32(2), 189-200. Retrieved from https://jalt-publications.org/sites/ default/files/pdf-article/perspectives.pdf

Savignon, S. (1997). Communicative competence theory and classroom practice: Texts and contexts in second language learning ( $2^{\text {nd }}$ edition). New York, NY: McGraw-Hill.

Tahira, M. (2012). Behind MEXT's new course of study guidelines. The Language Teacher, 36(3), 3-8. Retrieved from https://jalt-publications.org/files/pdf-article/36.3_art1.pdf

VanPatten, B. (2003). From input to output: A teacher's guide to second language acquisition. New York, NY: McGraw-Hill.

VanPatten, B. (2016). Why explicit knowledge cannot turn into implicit knowledge. Foreign Language Annals, 49(4), 650-657. https://doi.org/10.1111/flan.12226

VanPatten, B. (2017). While we're on the topic: BVP on language, acquisition, and classroom practice. Alexandria, VA: The American Council on the Teaching of Foreign Languages.

VanPatten, B. (Host). (2019a, April 11). Negotiation of meaning [Audio podcast]. In TalkinL2withBVP.

VanPatten, B. (2019b). Tenets of comprehension-based language teaching with a focus on communicative ability [PDF file]. Retrieved from https://www.inputandmore.com/talkin-12resources

VanPatten, B. (Host). (2019c, November 7). Why we argue about the role of grammar in language teaching [Audio podcast]. In TalkinL2withBVP.

VanPatten, B., \& Rothman, J. (2014). Against "rules." In A. Benati, C. Laval, \& M. J. Areche (Eds.), The grammar dimension in instructed second language acquisition: Theories, research and practice (pp. 15-35). London, England: Bloomsbury

Willis, J. (1996). A framework for task-based learning. Harlow, England: Longman.

\section{Appendix A}

Step One. Introduction: What Technology Habits Are Normal or Excessive?

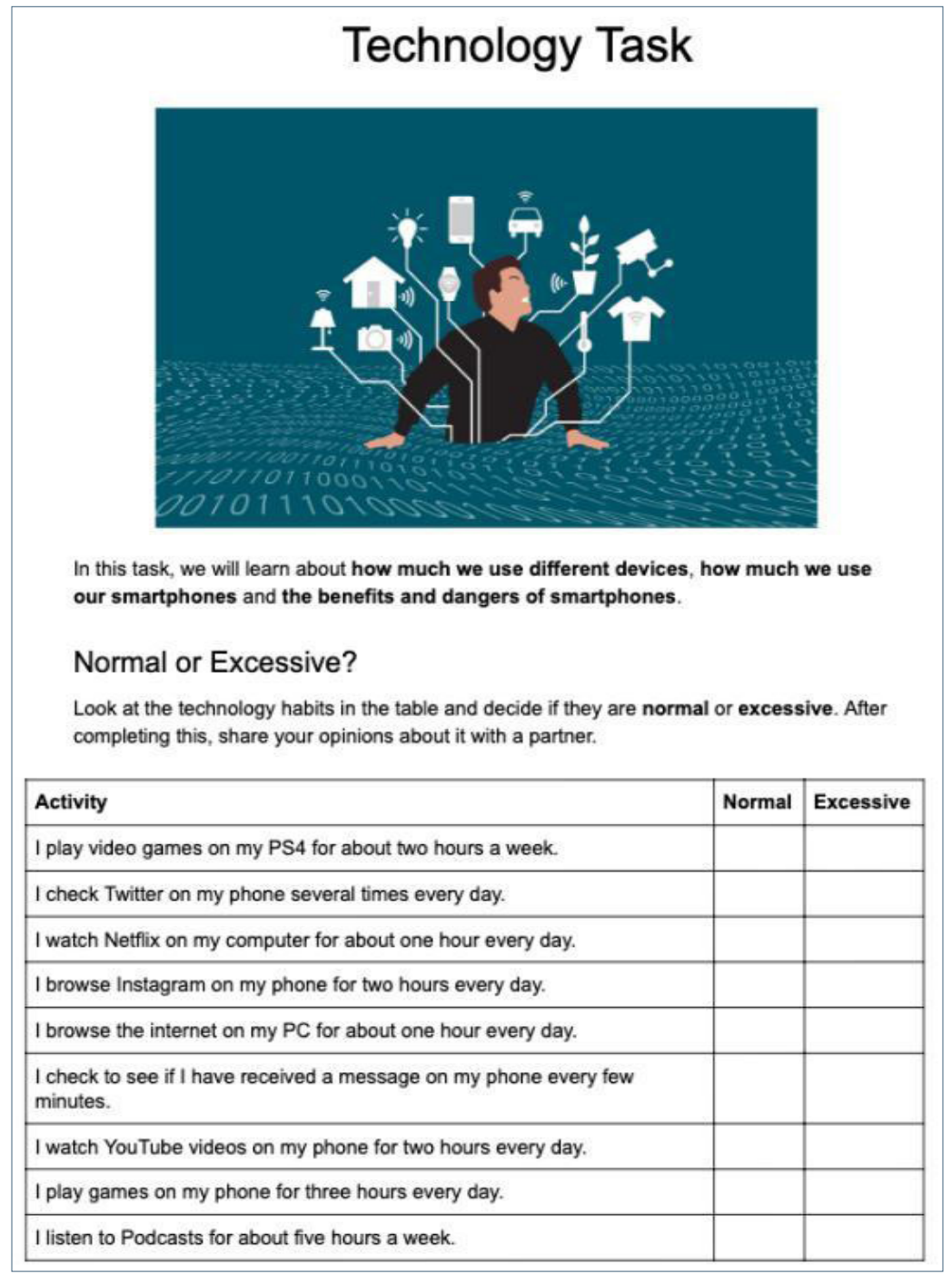


Appendix B

Step Two. Pair work: Electronic Device Survey

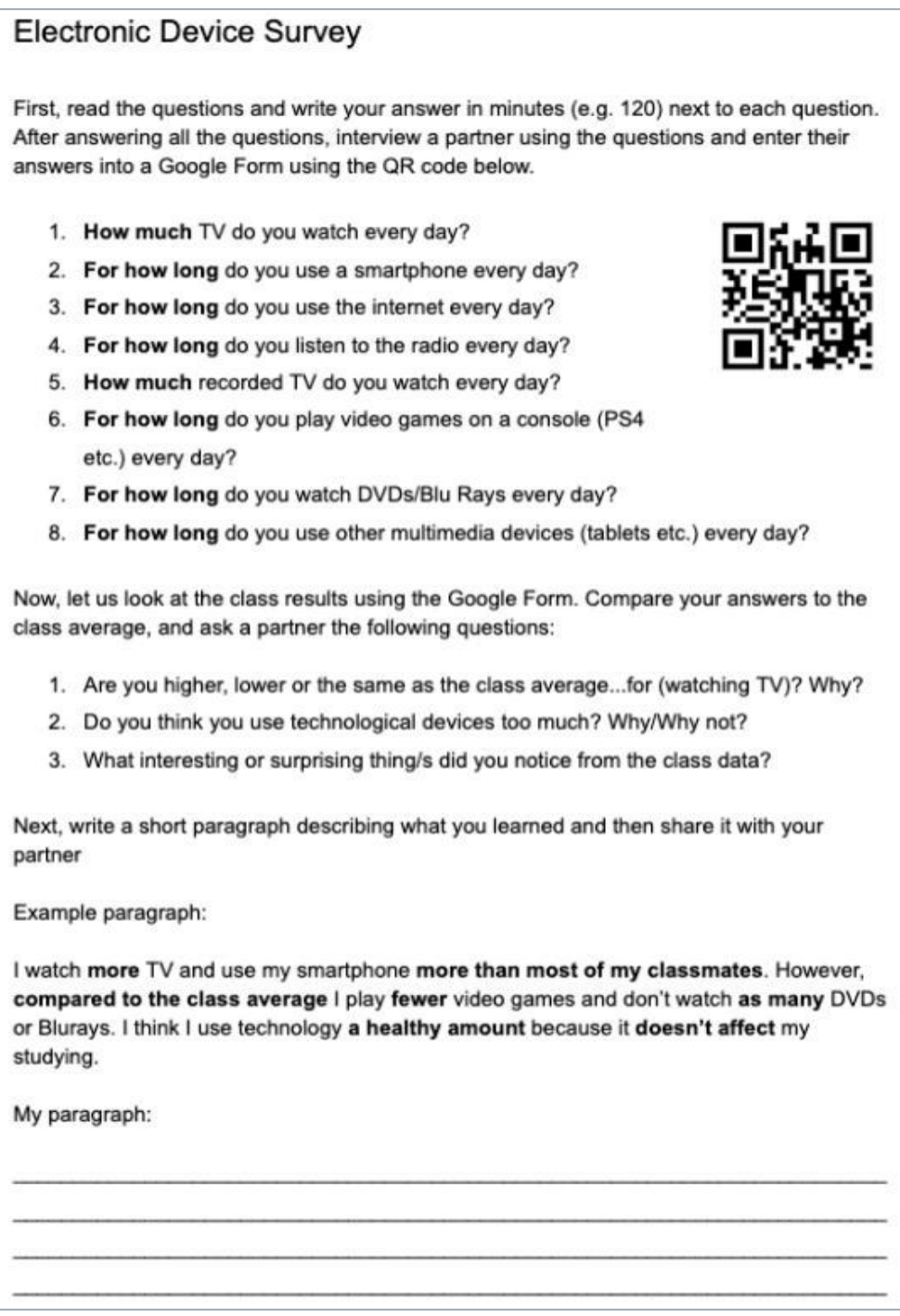

\section{Appendix C}

Step Four. Learn About the Wider World: The Benefits and Dangers of Smartphone Use

\section{Benefits and Dangers infographic.
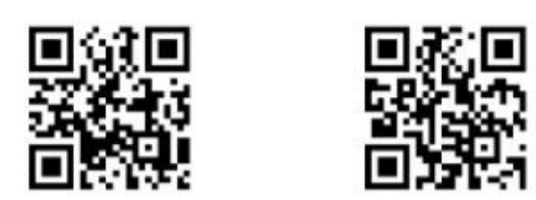

Now let us learn about the benefits and dangers of smartphones. Your instructor will give you the letter 'A', 'B' or ' $C$ '. Scan the corresponding QR below and read the infographic. Write down two things in the box below that you thought were interesting or surprising from the
A
B

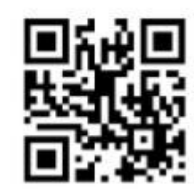

C
After writing down two things you thought were interesting, interview two other classmates and write down what they say in the box below. If you are ' $A$ ', you should interview someone who is ' $\mathrm{B}$ ' and ' $\mathrm{C}$ '.

\begin{tabular}{|l|l|l|}
\hline 2 Things I learned & $\begin{array}{l}2 \text { Things Classmate \#1 } \\
\text { learned }\end{array}$ & $\begin{array}{l}\text { 2 Things Classmates \#2 } \\
\text { learned }\end{array}$ \\
\hline & & \\
& & \\
\hline & & \\
& & \\
& & \\
\hline
\end{tabular}

After completing the table, ask a partner the following questions:

1. What was the most interesting or surprising thing you learned? Why?

2. Will you change any of your habits because of something you learned? Why/Why not? 